University of Wollongong

Research Online

Faculty of Law, Humanities and the Arts Papers (Archive)

Faculty of Arts, Social Sciences \& Humanities

$1-1-2017$

Stretching Out: Species Extinction and Planetary Aesthetics in Contemporary Art

Su Ballard

University of Wollongong, sballard@uow.edu.au

Follow this and additional works at: https://ro.uow.edu.au/lhapapers

Part of the Arts and Humanities Commons, and the Law Commons

Research Online is the open access institutional repository for the University of Wollongong. For further information contact the UOW Library: research-pubs@uow.edu.au 


\title{
Stretching Out: Species Extinction and Planetary Aesthetics in Contemporary Art
}

\author{
Abstract \\ There is madness in species extinction. The horn has been removed from the last male northern white \\ rhino on earth and he has two armed guards 24 hours a day. The huia in New Zealand were killed off by \\ the desire for white-tipped tail feathers in Victorian hats. We fear the extinction of rhinos, we mourn the \\ extinction of the huia, yet we might need reminding to also show concern for the extinction of the dung \\ beetle. This paper looks at the ways that artists are engaging with these difficult events. By placing \\ Gayatri Spivak's call for a planetarity of thought in conversation with Donna Haraway's practice of 'making \\ kin,' I argue that art history is a practice of planetary aesthetics. In discussion of recent works by Shannon \\ Te Ao, Francis Uprichard, Diana Thater, Agnieszka Golda and Martin Johnson, and Black Moss (Nathan \\ Hughes and Jinyi Wang), I show how artists are rethinking the moments when species meet in the \\ Anthropocene.

\section{Keywords} \\ out:, species, stretching, extinction, art, planetary, aesthetics, contemporary \\ Disciplines \\ Arts and Humanities | Law \\ Publication Details \\ Ballard, S. "Stretching Out: Species Extinction and Planetary Aesthetics in Contemporary Art." Australian \\ and New Zealand Journal of Art 17.1 (2017): 2-16.
}


Post-peer review MANUSCRIPT VERSION

May 2017

Accepted: Australian and New Zealand Journal of Art (RAJA).

DOI: http://dx.doi.org/10.1080/14434318.2017.1333403

Stretching Out: Species Extinction and Planetary Aesthetics

in Contemporary Art

Susan Ballard

sballard@uow.edu.au

\section{ABSTRACT:}

There is madness in species extinction. The horn has been removed from the last male northern white rhino on earth and he has two armed guards 24 hours a day. The huia in New Zealand were killed off by the desire for white-tipped tail feathers in Victorian hats. We fear the extinction of rhinos, we mourn the extinction of the huia, yet we might need reminding to also show concern for the extinction of the dung beetle. This paper looks at the ways that artists are engaging with these difficult events. By placing Gayatri Spivak's call for a planetarity of thought in conversation with Donna Haraway's practice of 'making kin,' I argue that art history is a practice of planetary aesthetics. In discussion of recent works by Shannon Te Ao, Francis Uprichard, Diana Thater, Agnieszka Golda and Martin Johnson, and Black Moss (Nathan Hughes and Jinyi Wang), I show how artists are rethinking the moments when species meet in the Anthropocene.

Keywords: species extinction, Anthropocene, contemporary art, planetarity, kin. 
If we judge our actions innocent and we win, we win nothing, history goes on as before, but if we lose, we lose everything, being unprepared for some possible catastrophe. ${ }^{1}$

A desolate monkey wears a fur coat to its own burial. Another animal, perhaps also a monkey, definitely simian, attends the same ritual a few years later; this time there is a little more context. This second creature plays the role of guru. Others look to it for answers. It is likely that it has something to say about extinction, and the audience has many questions. Francis Upritchard's Mask monkey (2009) and Ug monkey (2009, fig. 1) each represent a human urge to understand. The monkeys perform a service that helps humans imagine what a species is, or might become. The dreams we place onto these creatures constantly turn back on us; as if these miniature inert figures of modelling clay, fur, and recycled leather contain the memories of a former utopian life. Passive, weighty, silent, and mournful, Upritchard's visionary creatures observe humans who are being challenged by the unnerving idea of their own extinction.

In another room, in another country, the single-screen video installation Two shoots that stretch far out (2013-14, fig. 2 and 3) by Shannon Te Ao strikes at the limitations of such multispecies communication. The work is simple: Te Ao mournfully recites a series of English translations of a pre-colonial waiata, 'A Song About Two Wives,' to a shed full of disinterested animals. As it is repeated each translation is slightly different, yet the words convey a desperate need to connect, 
while Te Ao's flat-voiced presentation of the monologue obscures the urgency of the situation. These ducks, rabbits, chickens, donkey, swan, and wallaby are only listening politely. The setting is an animal-wrangling farm and the animals are trained professional actors—-this is their rehearsal space. They tolerate this morose, somewhat self-centred invader who seems to have taken up residence in their barn, but they also seem to be waiting for some real communication to begin.

These works by New Zealand artists Shannon Te Ao and Francis Upritchard contain aesthetic moments in which species meet. ${ }^{2}$ They each stretch the definitions of what a species might be in order to think beyond the human. Both works question the kinds of truths we sometimes expect artworks and the animals within them, both human and nonhuman, to tell. This essay extends out from these two works to think about the implications that species extinction has for writing art history today. Until very recently, art history's engagement with human-animal relationships has been through a romantic and representational lens that is no longer suitable for a time of crisis. ${ }^{3}$ The way that we have written about the relationships between humans and other species is via texts and art works that trade in metaphorical and utopian narratives of either wonder or horror. ${ }^{4}$ Artists have confronted viewers with species long extinct, or generated fantastical worlds where humans and animals work together in harmony. ${ }^{5}$ This regular practice has been challenged by events and moments of contact that have occurred at times of extreme and unfathomable crisis. After the thrills of identification and classification that marked modernity's engagement with animals, the recognition of a sudden loss of species required a 
different approach. For example, the rapid loss of New Zealand birdlife was a catastrophe that continues to generate responses. Amongst many others, Bill Hammond, Fiona Pardington, Hayden Fowler, Stella Brennan, Colin McCahon, Joanna Braithwaite, Shane Cotton, Don Binney, and Michael Harrison have all told small fragments of the story.

An approach to extinction that engages with discomfort at a planetary scale is a turning point in this story of the catastrophe of species. Artists have approached the crisis of the Anthropocene and the acceleration of major extinction events with works that turn to the nonhuman world and critique previous anthropocentric representations. ${ }^{6}$ For example, when thinking about her photographs of dead huia, taken within museum collections, Fiona Pardington says she takes the photographs in order to 'talk about the uncomfortable things'. ${ }^{7}$ But what is also called for is a revisiting of art history and its narratives. Firstly, art history needs to address the impacts of extinction on how artists have engaged with multispecies relationships in their works. And secondly, art historians need to draw on our disciplinary knowledge of representation and imagination to challenge the global inequities of the Anthropocene. One way we can do this is to align our texts with the critical approach to literary theory suggested by Indian writer Gayatri Spivak. ${ }^{8}$ Spivak has called for an investment in a planetarity, or planetary-thinking, that takes the economic and social differences of globalisation seriously and that does not default to a gendered notion of 'mother earth'. 9 An art history written within the Anthropocene then, looks at the way in which artists do much more than reflect and mourn catastrophic disaster; it 
addresses the way that artists contribute new aesthetic futures for understanding planetary relationships.

\section{Cape Grim}

Rapid species extinction is one of the key markers of the Anthropocene. The term Anthropocene refers to 'the period of Earth's history during which humans have a decisive influence on the state, dynamics and future of the Earth system'. ${ }^{10}$ Currently, an interdisciplinary working group of scientists are gathering to consider if the name Anthropocene will be formally adopted as a geological epoch. On 23 February 2016 the Subcommission on Quaternary Stratigraphy, known as the 'Working Group on the "Anthropocene" published an interim report that listed some of the possible markers being considered. In order for the committee to be persuaded, they will require that the geological sign be large and distinct. Like that of previous mass extinctions, the chemical signature of transformation must appear in the geological strata. This planetary transformation is being hunted in the ice cores of the rapidly melting arctic, the agricultural sediments accumulating in the Yellow Sea and the shifting atmospheric gases in Antarctica. ${ }^{11}$ Markers keep failing. However, at 8 am on 10 May 2016 a new milestone for the Anthropocene was reached. The southern hemisphere baseline $\mathrm{CO} 2$ reading, measured at Cape Grim in Tasmania, finally crossed the 400ppm milestone. ${ }^{12}$ Humans have now transformed the geological record not just locally but planetarily. 
The precise starting date of the Anthropocene is only one part of the debate. Another aspect is the need to identify a record that will stay beyond us, that will be visible in sediment and rock millions of years into the future. This is the shock; not that the Anthropocene is about turning towards the human, or that the human species has a collective ego that will take over and stamp its mark in the strata, but that humanity will be the first species to slip into geology not as a record but as a force. ${ }^{13}$ Like the fish that have transformed their metabolism to consume plastic, we are a transformative part of the environment and it is part of us.

\section{Planetary aesthetics}

The need to understand the implications of the Anthropocene means that we must shift our understanding of species, not only as a frame for looking and mapping but also as a potentially flawed means of differentiation. In noting that this is a very real job, American feminist theorist Donna Haraway suggests that we join forces with other 'mortal critters'. ${ }^{14}$ Haraway's practice of 'making kin' is about creating stories that gather the complexities of bodies that might lie outside the binary of human and nonhuman. This turn to a consideration of the nonhuman is already prevalent in the work of artists who are considering the critical contexts of animal studies, but I think we need to travel more widely. The imaginative worlds of artists who eschew any particular disciplinary location, like Upritchard and Te Ao, help us to think not only of species extinctions as a key biological marker of the Anthropocene but to move towards a rethinking of the planet and the future of the species upon it. The works 
approach some of the trauma of what it means to live in the Anthropocene.

Challenging the factual narrative of species loss and countering it with a discussion of what happens when species meet leads to the emergence of a new kind of planetary aesthetics in contemporary art. The next step then, is to address the various scales of such meetings.

Haraway and Spivak each figure an approach to the Anthropocene that does not discriminate between species. Spivak offers 'planet-thinking' and 'planet-feeling' as a counter to the ways that humans have divided our understandings of the world into self and other, subject and object, human and nonhuman. ${ }^{15}$ Haraway says that one way to approach the issue of scale is to address 'the fact that all earthlings are kin in the deepest sense'. ${ }^{16}$ When read together, their works embrace multispecies ways of knowing within the myriad of material and ecological understandings of this planet. ${ }^{17}$ For art history, they offer a way to think about the relationship of art practices to the species crises of the Anthropocene. Art history is about looking. In the critical context of the Anthropocene, the species extinctions that make up just one small part of the larger event of climate change mean that it is necessary to employ a method in which looking is informed by a broader ethico-aesthetics of thought, and this is where writing about art becomes one way of addressing the planetary meetings of species. To use this holistic and ethical approach as an aesthetic tool means working within a practice of art history that includes moments of contact, whether they be between birds, monkeys, wombats, dung beetles, humans or machines. 


\section{Science, fiction}

Of particular interest in this context are art works that avoid drawing disciplinary or thematic distinctions between the planet, its species, its histories and the way in which we might record and respond to crisis. American artist Diana Thater often inserts her audience inside what she calls 'animal spaces,' constructed within an art gallery. ${ }^{18}$ As visitors to these environments, we sense and feel different spatial energies through varying frequencies of light. Thater's recent work Science, fiction (2014) ${ }^{19}$ was developed as a response to an article published in Current Biology that showed how a species of dung beetle uses the Milky Way to orientate themselves in space. ${ }^{20}$ The intense competition in a dung heap means that as soon as a male beetle has carefully manufactured an individual ball of dung, they will roll it away from the heap as fast as they can. The best method is in a straight line, ideally with a female along for the ride.

Often discussions of the dung beetle tend towards their importance within the environmental service industry. Some researchers have even tried to work out the economic worth of the beetle's efforts in cleaning up cow manure. ${ }^{21}$ The beetle's value in Thater's installation is not monetary but cosmic, planetary. Every surface of the installation is tainted with a glowing pure blue spectrum. In the centre of the main gallery a box seems to levitate. Projected onto the ceiling above the box is a video of dung beetles crawling through brown straw and manure. The boxed space in the centre of the room was blocked off, the effect being like that of viewing a city 
from a great distance at night, where the shape and form of the city itself is obscured by the light pollution from urban and industrial sites. In Thater's upside-down world, there, in the sky where you would expect to see the stars, were the beetles themselves. In their attempts to enfold matter, to make use of waste in order to feed the next generation, the dung beetles are here prevented from finding their way.

But the life of a dung beetle is more than work. This is not a Pixar movie where anthropomorphised insects perform human stereotypes. Thater's understanding of the beetles was further communicated in the next room, which was also bathed in blue light. There, Thater installed a room of flat screen TVs containing visualisations of the galaxy that seem to float independent of scale and location..$^{22}$ In the corner of two of the TVs was an image of a Death-Star-looking optical device: a Zeiss star projector similar to the one used by the researchers in the original dung beetle report. After testing the straight-line running techniques of the beetles in the field, the researchers moved their 'arena' to the Johannesburg planetarium, and using the Zeiss star projector they demonstrated that the beetles weren't just using a single bright 'lodestar' but the more complex meanderings of the Milky Way. ${ }^{23}$

Thater named the video works after Galileo's first essay, which documented his observations with telescopes. Like the planetarium, the telescope enables us to see sights that our bodies cannot reach. In Thater's works, the image of the Zeiss star projector reverses the way in which Galileo's telescopes revealed the horrors of a pock-marked rather than smooth-skinned moon: the star projector can project only 
the known, only what has been mapped so far. This is in no way a representation of all the wonders a cow in a field might see if she ignored the beetles at her feet and turned her head to the sky - an experience somewhat in common with the way that Thater turns to the vast scale of planetary-thinking. Thater's project shows how problems that might seem human are also beyond the human, and can perhaps only be solved through multispecies understandings at a planetary scale.

Spivak emphasises that although planetary thought opens up spaces outside of the global, the earthy, and the cosmopolitan, planetarity is not a formula. Spivak's technique is to dis-figure the earth by moving away from the global, insisting that we learn how to read what is around us. For Spivak, like Haraway, to think the planet is to think in terms of an undivided natural space, not something limitless, but a space that is limited by the planet itself, and for which we maintain a communal responsibility. In Thater's installation, the communal responsibility is found in the way that dung beetle knowledge expands beyond the planet. Their knowledge of the universe is founded in small planetary ecosystems. Thater immerses viewers in an imitation of their world; making us crane our necks in order to grasp the enormity of the gaze of the dung beetle, and then obscuring the very same gaze with light pollution. In doing so, Thater forces us to confront our own contributions to dung beetle extinction.

In her thinking on the species disaster of the Anthropocene, Spivak turns to the species disaster that is the human, that constantly draws boundaries and says: 'I am 
different to you. We are different.' Spivak does not directly address the nonhuman animal, however, her examples introduce relationships that exist at a planetary scale across and over time. Spivak argues that even in the Anthropocene, when we have made epoch-changing impacts on the earth's systems, humans continue to act as if there is something specific about being human: something to do with species and fixity, rather than alterity. This planetary alterity is something that is immediately understood in the impossible multispecies conjunction of dung beetle extinction, the cosmos, and a monkey in a fur coat. As Haraway says, an understanding of all earthlings as kin challenges operations of scale that adhere to quantifiable understanding of otherness. Understanding the planet through alterity includes the human as another kind of adaptive creature, nothing special. It is a practice of negotiating relationships on the ground.

\section{Meeting not Othering}

Shannon Te Ao's Two Shoots that stretch far out (2014, fig. 2-3) premiered at the 2014 Sydney Biennale, and was installed in a large empty space so that a particular kind of distanced intimacy occurred between the viewer and what was on the screen-the ecosystem depicted in the video was also observed from afar. On screen is a man who seems to be trying to communicate with an assortment of animals. The viewer became a double imposition in the space: not present within the videoed room, yet somehow implicated as another human body within its spaces; listening and watching but unable to contribute. Te Ao filmed the sequences at an animal 
wrangling farm. The animals are not stressed by the environment, or his presence, but like us, are not completely at home either.

Throughout the video, Te Ao recites a lament written by Matahira, the senior wife of Te Kotiri of Ngāti Porou, after Te Kotiri took on his second wife. In Te Ao's work, the words of a once powerful woman are revived and occupy a new world. Te Ao explains that the proverb is about connection to people and ancestry. ${ }^{24}$ It is also about living systems and lived experience. Central to Te Ao's interpretation of the lament is the impossibility of directionality. The two shoots that wind their way out from a gourd are forever seeking contact. Spreading themselves wide they travel in very different directions. Through listening to the repetitions of Matahira's lament, we become entangled with the animals in the room. The gendered voice is at first imperceptible and becomes stronger with each retelling, as alongside each animal we listen to a slightly different translation. Te Ao revisits love and loss within the histories of colonisation, and by knotting together the romance of the individual with an enclosed model of nature, he questions the usual myths of multispecies communication. Faced with an unresponsive audience, Te Ao's attempts at making kin are met with disinterest.

Te Ao, Thater and Upritchard are not the first artists to explore kinship across species, and there is an earlier art work that laid down some of these parameters for multispecies communication and empathy. In 1965, Joseph Beuys staged a performance in which he explained art to a dead hare. ${ }^{25}$ In a locked and empty gallery 
with gold leaf and honey smeared on his head and a magnetic iron plate strapped to his foot, Beuys could be seen whispering to the hare cradled in his arms. Beuys later commented that 'everyone unconsciously recognises the problem of explaining things.... The problem lies in the word "understanding" and its many levels that cannot be restricted to rational analysis' ${ }^{26}$ Beuys says that it is in our imagining of understanding that humans give away their longing for connection.

Te Ao models his engagement on Beuys. For Te Ao, the absurdity of the gesture is contained within the patience of the animals. Listening to humans is what these animals do for their jobs, and this is their training barn, where they work. Te Ao's actions begin to ring with anger. Matahira is furious. How could her husband, with whom she has entwined her limbs 'like drifting weeds of the river' now shift his affections to another? Her 'body is sorely stricken'. It is too easy to conflate her body with that of the animals around her. Ironically, it is Te Ao's presence that prevents this happening, he/she cannot be reduced to mother nature. In this barn everyone inhabits a moment of meeting, a moment that redefines a way of knowing. Te Ao writes:

Sharing a lament ... I am ambling with a frail, housebound marsupial. I recite thoughts of loss and despair and through my voice; Matahira hears the muffled score of her estranged spouse and his new lover. Walloo is ushered around the small space of the training barn as he brushes the inside of my legs and feet. I anticipate and simultaneously shadow his movements while he uses my presence to plot his own bearings. Meanwhile, the voice of Matahira observes through the wall, the heavy breathing from the next room. ${ }^{27}$

The animals in Te Ao's video see a body out of place, an individual with something on his mind. The donkey nudges him, the wallaby uses his touch as a guide. Hopeful 
connections are made and bodies meet in the model of the human embodied by Te Ao.

\section{Vulnerability}

Spivak argues that planetarity allows for a different figuring of human being: not as continental beings; nor global (the non-stop 11,000-kilometre flight paths of the bartailed godwit can tell us this); ${ }^{28}$ and not earthly_nurturing the earth or being nurtured by it is no longer enough. In thinking planetary aesthetics, other forces need to come into play.

The size of the problem is underscored by numerous local events; however, the scale of the Anthropocene means that the local and the planetary cannot be considered in binary opposition. Like much of the rest of the world, Australia is undergoing a rapid loss of its land-based species. There are numerous small moments of loss, each with planetary impact. Despite small moments of hope, over the past forty years Burhinus grallarius, or the bush stone-curlew, has been considered locally extinct in New South Wales, Australia. Once common due to its fantastic camouflage, allowing it to seemingly melt into leaf litter, the bird suffered a dramatic decline due to predators, agricultural monocultures and urban expansion. ${ }^{29}$ The language used by ecologists to describe the disappearance of species is narrow and yet nonspecific. When does a species slip from 'near threatened' to 'vulnerable' to 'extinct'? ${ }^{30}$ When can an individual turn away from us and just get on with the business of being a bird? 
Australian artists Agnieszka Golda and Martin Johnson are building an army of phantoms-animals that contain energies that enable them to cross between worlds — and leading the army is the Bush stone-curlew (fig. 4). The encounter with this carved wooden child-sized creature is startling: it is as if it has only recently escaped from Mastro Geppetto's workshop. Golda and Johnson do not directly represent the bird, instead they suggest that the bird has its own way of doing things. In the context of this project, Golda and Johnson work to return the bush stonecurlew the authority of its own existence- a process through which it establishes dignity in the face of uncertainty. In this new multispecies form, its 'thick knees' help it to stand tall.

When frightened, the bush stone-curlew lies flat to the ground with its neck outstretched. But this bird claims territory. Golda and Johnson's bird perches on a lump of found concrete; an inadequate adaption that may contribute to its survival. Like Upritchard's gang of unruly misfits, Golda and Johnson's Bush stone-curlew is one work among many that point to other ways of figuring the planet. This bird is an individual, alongside others, navigating the madness of hope and despair.

One of Spivak's touchstones is Mahasweta Devi's short story 'Pterodactyl, Puran Sahay, and Pirtha' (1993), a tale of postcolonial states and indigenous legal collectivity. ${ }^{31}$ It has a pterodactyl at its core: an animal that knew the planet before there were continents, before continental drift, before nation states. Spivak says, 'the 
figure of the pterodactyl can claim the entire planet as its other. It is prior to our thinking of continents' ${ }^{32}$ The characters in the story talk with the pterodactyl, trying to remind it of its location in time and space: 'When the continents drifted again and took their current shape ... you were supposed to have become extinct. ${ }^{33}$ The possibility is haunting both for the journalist trying to break the story of the presence of the pterodactyl, and the individuals aware of their own potential future extinction. With the Bush stone-curlew, Golda and Johnson introduce a process of repair and recovery into these narratives of multispecies encounter, and Golda talks of her concern for art to 'generate spaces of encounter' between species. ${ }^{34}$

Encountered in the gallery, Golda and Johnson's bird stands in front of enormous theatrical wall hangings that block out the outside world. ${ }^{35}$ These backdrops construct mobile scenes through which the bird can tell stories. In this storytelling, its cultural poetics extend out to the planetary, and its borrowed anime eyes reflect knowledge of other birds, from other places. Like Devi's pterodactyl, Golda and Johnson's bird is thinking of the spaces where we live as a parallel body; it is an uncanny place where imagination rules. Here, it seems, artists can do something: by building an army of resistance at the moment when species meet, Golda and Johnson suggest that a new kind of planetary empathy might enable a new kind of living. As a planetary phantom, the Bush stone-curlew is a proxy for our understanding of planetary aesthetics.

\section{Love and extinction}


A woman finds a magical thing on the seashore. Emanating a glowing aura, it is unrecognisable and cannot be categorised. It has the body of a deep-sea creature, yet the materials of some newly found multidimensional substance. It glows with an energy that seems to communicate life. The mysterious object may be a new species. The woman travels with it, first to an ancient fairground, and then to a headlandthe kind of place where spirits depart. In the single-screen video Object (2015, fig. 5 and 6), by the nomadic research lab Black Moss (Jinyi Wang and Nathan Hughes), the object-thing appears to hold magical powers, and the woman holds it close to her body. ${ }^{36}$ The video stills our attention as it resists familiar forms of narrative at the same time as it draws us in to an intimate relationship with the protagonists. Wang and Hughes direct us away from the pathos of species mourning or loss, and towards an ethics of care and wonder. It is a different kind of meeting, of kin, of possible species.

Previously, when trying to understand an unknowable planet, Western authors, artists and philosophers constructed a new term: the wilderness described a land inhabited only by wild animals. The concept drew on observations of 'wild deer' and was a way of thinking nature outside of the natural environment humans had tamed and named Mother Earth. The wilderness: a species that becomes a place. The wilds were close to towns, often within walking distance, and were a site of release and uncertainty. The wilds contained mythical spaces, where little girls should not roam alone. As amateur naturalists travelled further and further into the wilds, the science 
of species expanded further. By the early nineteenth century, Darwin explained that the divisions between species were not discrete stratifications, and that we needed to pay attention to the evolution and selection of species—sexual, natural, and powerful. In arguing for the origin of species, Darwin shifted the family tree, and it all accelerated from there. First, industrialisation, and the release of plutonium and Carbon-14 that transformed the earth's atmosphere. Likewise, there have been massive shifts in the chemical and mineral make up of the earth (the periodic table of the elements has been updated to reflect this). All this transformation is anthropogenic: humans are simultaneously adding to and destroying the planet's evolutionary map. When I imagine this new world made from techno-materials, monocultures, aluminium, concrete, and plastic it seems sensible to follow Haraway and Spivak in moving away from the taxonomy of species and towards a new kind of planet-thinking. Yet, in figuring new relationships there is always the risk, once again, of placing the human at the centre of things.

Art and its histories are not in competition with the sciences, both hard and soft. Instead, those of us working alongside the practices of art do what we do best: we imagine and describe what we do not yet know. As Spivak says, our work is 'vague, unverifiable and iterable' but we do not put it aside. ${ }^{37}$ We didn't put feminism aside for the very same reason. We hold onto our vague, unverifiable and iterable tools because these are the things that make us responsible, responsive and answerable. In Wang and Hughes's Object nothing is verifiable, but what is clear is the relationship 
the woman forms with the object. She takes responsibility for its care, and in return it offers something vague, unverifiable and iterable back.

The art works I've discussed here all focus on the interrelationships and making kin (or being with) of species. As I have tried to highlight, the problem of the definition and separation of species, and thus also that of extinction, sits within the Western 'tradition' of the division between human and nonhuman. Extinction is embedded in the very definition of species. Neel Ahuja argues that we need to address multispecies social formations by disentangling the discourses of race and species, and decentring the privileged geographical sites of analysis. ${ }^{38} \mathrm{He}$ writes, 'Enlightenment conceptions of animals ... relied on the same objectifying methods used to represent slaves and the poor: sentimentality, representations of cruelty, [and] humane manifestos. ${ }^{39} \mathrm{I}$ have suggested that by turning to moments of multispecies encounter, artists have done much of the work of untangling this inequity. The ecologies of representation addressed by Francis Upritchard, Shannon Te Ao, Diana Thater, Agnieszka Golda and Martin Johnson, and Black Moss are just some examples where a rethinking of the boundaries of species leads to an opening up of planetary thought. These artists trace 'situated zones of contact between people and nonhuman species' ${ }^{40}$ without resorting to didactics or formulas to save the world.

Humans have already made an imprint on the earth, and our actions are recorded in the unrefined concrete that Golda and Johnson's birds use as perches, and the wooden barn occupied by the animals in Te Ao's video. These are architectures that 
already contain the markers of the Anthropocene. The works discussed in this essay name the Anthropocene as a planetary site where species meet. These are troubling works, and this troubled spot is exactly where the impact of extinction comes into play. Thinking about when species meet means we must include in our art histories telescopes and dung beetles, potted plants and sleeping swans, monkeys in fur coats, and birds with eyes sutured from another time and place. These are images of life at every scale.

Te Ao indexes human knowledge with a praxis that tells us we better start doing things by paying attention to where we have been. Thater offers another space for magical thinking and a method for communication, a useful form of stretching across what until now we have called species. Upritchard shifts beyond a speculative or magical space into a wondrous world of new creatures, again pushing at the boundaries of what we imagine species to be. Golda and Johnson offer a body back to a terrified yet dignified animal barely able to maintain its ecosystem. And, Wang and Hughes shift the boundaries of what we might recognise as a nonhuman species by offering the object-thing the love of a companion species, or kin. A planetary image of the Anthropocene might look like a sorrowful man talking to animals in a barn, but it might also look like a field of industrious dung beetles, a lonely starship drifting amidst a virtual cosmos of its own making, and a bird stretching itself up tall and staring at us through borrowed eyes. The artists discussed in this essay show how contemporary art opens up thresholds for thinking planetary aesthetics. These are the 
meeting points at which companion species (no longer defined by gender, biology or humanity) test that which is no longer accepted: the boundaries of survival.

\section{LIST OF FIGURES}

Figure 1. Francis Upritchard, Mask monkey (2009). Fur, leather, modelling materials, $35.8 \times 33.8 \times 37.4 \mathrm{~cm}$; $U g$ monkey, 2009. Fur, leather, modelling materials, $51.1 \times$ 61.4 x $60.7 \mathrm{~cm}$. Reproduced courtesy of the artist and Kate Macgarry Gallery, London.

Figure 2. Shannon Te Ao, Two shoots that stretch far out, 2013-14. Single-channel video, colour, sound, 13:22 min. Cinematography: Iain Frengley. Reproduced courtesy of the artist and Robert Heald Gallery.

Figure 3. Shannon Te Ao, Two shoots that stretch far out, 2013-14. Single-channel video, colour, sound, 13:22 min. Cinematography: Iain Frengley. Installation view: From the one I call my own: Susan Te Kahurangi King \& Shannon Te Ao City Gallery Wellington, 2016. Image: Shaun Waugh. Reproduced courtesy of the artist and Robert Heald Gallery. 
Figure 4. Agnieszka Golda and Martin Johnson, Bush stone-curlew, 2016. Acrylic on found wood and concrete, $130 \times 70 \mathrm{~cm}$; installation view from mixed-media installation For Everything That Is ..., 2016. Reproduced courtesy of the artists.

Figure 5. Jinyi Wang and Nathan Hughes [Black Moss], Object, 2015. Singlechannel video, colour, sound, 5:53 min loop. Available at: http://tcjournal.org/drupal/vol6/blackmoss. Reproduced courtesy of the artists. Figure 6. Jinyi Wang and Nathan Hughes [Black Moss], Object, 2015. Singlechannel video, colour, sound, 5:53 min loop. Available at: http://tcjournal.org/drupal/vol6/blackmoss. Reproduced courtesy of the artists. 
${ }^{1}$ Michel Serres, The Natural Contract, trans. Elizabeth MacArthur and William Paulson (Ann Arbor: University of Michigan Press, 1995), 5. Serres describes a series of ecological tipping points, arguing that it is necessary to rethink the relationship between species, beginning from the discourses of mastery and control that frame everything in terms of war and property. He suggests that without this fundamental rethinking of our 'contract' with nature, we will be 'unprepared for some possible catastrophe'.

${ }^{2}$ The phrase 'when species meet' is the title of a book by Donna Haraway and my readings of her work pervade this essay. Donna Haraway, When Species Meet (Minneapolis and London: University of Minnesota Press, 2008).

${ }^{3}$ T. J. Demos has shown how art history is a practice that both documents and challenges what it is that artists are doing, adding that it too must turn towards the larger frames of thinking offered by the Anthropocene. T. J. Demos, 'Decolonizing Nature: Making the World Matter', Social Text, (March 2015). http://socialtextjournal.org/periscope_article/decolonizing-nature-making-the-worldmatter/ (Accessed: 8 May 2017)

${ }^{4}$ For more recent approaches to the human-animal relationship, see: Human Animal Research Network Editorial Collective, Animals in the Anthropocene: Critical Perspectives on Non-human Futures (Sydney: Sydney University Press, 2015); and, Laurence Simmons and Philip Armstrong, Knowing Animals (London: Brill, 2007). 
${ }^{5}$ This approach is challenged by recent work in Animal Studies, see: Annie Potts, Philip Armstrong and Deidre Brown, A New Zealand Book of Beasts: Animals in our History, Culture and Everyday Life (Auckland: Auckland University Press, 2013). ${ }^{6}$ See Heather Davis and Etienne Turpin, Art in the Anthropocene: Encounters Among Aesthetics, Politics, Environments and Epistemologies (Sydney: Open Humanities Press, 2015).

${ }^{7}$ Fiona Pardington, Ake ake huia, 2016. Audio, Auckland Art Gallery, 3:24 mins. http://www.aucklandartgallery.com/page/fiona-pardington-ake-ake-huia (Accessed: 8 May 2017). See: Fiona Pardington, Portrait of a female huia, heterolocha acuitirostris, 2004. Gelatin silver photograph printed on fibre-based archival paper. Stark White Gallery.

${ }^{8}$ Spivak introduces 'planetarity' in Gayatri Chakravorty Spivak, Death of a Discipline (New York: Columbia University Press, 2003). She further extends the potential of the concept in a number of essays including: Gayatri Chakravorty Spivak, 'World Systems and the Creole', Narrative 14, no. 6, (January 2006): 102-12; Gayatri Chakravorty Spivak, 'Ethics and Politics in Tagore, Coetzee, and Certain Scenes of Teaching', Diacritics 32, nos 3-4 (2002): 17-31. Rpt. in An Aesthetic Education in the Era of Globalization (Cambridge, MA: Harvard University Press, 2012), 316-34; Gayatri Chakravorty Spivak, Imperatives to Re-Imagine the Planet (Wien: Passagen Verlag, 1999).

${ }^{9}$ Spivak's argument is for the disciplines of Comparative Literature and Area Studies to figure themselves differently, which means to imagine themselves 'as planetary 
rather than continental, global or worldly'. (Spivak, Death of a Discipline, 72.)

Claiming the planet in this way presents an ethical alternative to globalisation. Spivak's issue is with the way that 'globalisation is the imposition of the same system of exchange everywhere' (Spivak, Death of a Discipline, 72.) Thinking the global enforces the circulation of geographical inequalities. At a material level the global world is cartographic. It is drawn all over with latitude and longitude measurements now translated into Google Earth systems that trace and map movements. Spivak says, 'The globe is on our computers. No one lives there.' (Spivak, Death of a Discipline, 72.) This is the computerised economics of globalisation. It is pervasive and ancient but has somehow transformed everything. The wealthy fly above, the goods travel by ship, and the dispossessed attempt small journeys in boats not up to the task. Small journeys that are deeply global, yet not understood by the planet.

${ }^{10}$ International Commission on Stratigraphy, Subcommission on Quaternary Stratigraphy, 'Working Group on the Anthropocene', 23 February 2016, http://quaternary.stratigraphy.org/workinggroups/anthropocene/ (Accessed 8 May 2017).

${ }^{11}$ Richard Monastersky, 'Anthropocene: The Human Age', Nature, 519, no. 7542 (11 March 2015), http://www.nature.com/news/anthropocene-the-human-age1.17085 (Accessed 8 May 2017).

${ }^{12}$ Peter Hannam, 'Confirmed: Southern Hemisphere CO2 level rises above symbolic 400ppm milestone', The Sydney Morning Herald, 16 May 2016, http://www.smh.com.au/environment/climate-change/confirmed-southern- 
hemisphere-co2-level-rises-above-symbolic-400-ppm-milestone-20160515-

govfq7.html (Accessed 8 May 2017).

${ }^{13}$ This challenge to the scientific framing of the Anthropocene has begun to happen in other humanities disciplines. In literary studies, Rob Nixon turns to writers whose work addresses to the overlooked and dispersed events of the Anthropocene that are 'incremental and accretive ... playing out across a range of temporal scales'. Rob Nixon, Slow Violence and the Environmentalism of the Poor (Harvard: Harvard University Press, 2013), 2. Historian Dipesh Chakrabarty has also identified how in the context of the Anthropocene distinctions between natural history and human history have collapsed. Dipesh Chakrabarty, 'The Climate of History: Four Theses', Critical Inquiry 35 (Winter 2009): 197-222. Nixon and Chakrabarty draw on the knowledges of both postcolonial theory and environmental criticism while highlighting how the repercussions of the Anthropocene are driving the need to shift disciplinary boundaries.

${ }^{14}$ Donna Haraway, Staying with the Trouble: Making Kin in the Chthulucene (Durham and London: Duke University Press, 2016), 101.

${ }^{15}$ Spivak, 'World Systems and the Creole', 108. For an application of Spivak's work to literary studies see: Duncan McColl Chesney 'Humans among the Other Animals: Planetarity, Responsibility, and Fiction in Disgrace and Wolf Totem', Concentric: Literacy and Cultural Studies 40, iss. 2 (September 2014): 175-201.

${ }^{16}$ Donna Haraway, Staying with the Trouble: Making Kin in the Chthulucene, 103. 
${ }^{17}$ This work has been happening in the fields of animal studies, creative writing, and eco-criticism for a number of years. See, for example Joshua Lobb's short story that entangles Jacob Von Uexküll's Umwelt with the Anthropocene. Joshua Lobb, 'What he Heard', Animal Studies Journal 4, no. 2 (2015): 176-180.

${ }^{18}$ MOCA, 'Diana Thater—Light and Space—-The Artist's Studio' MOCAtv, 1 October 2012, https://www.youtube.com/watch?v=nm1Xy34kJMA (Accessed 8 May 2017)

${ }^{19}$ Diana Thater, Science, fiction, 2014. Installation for two video projectors, watchout system, and lights, dimensions variable. The work was first exhibited at David Zwirner Gallery New York 2015. Documentation of the work available: http://www.thaterstudio.com/collections/view/works/science-fiction/ (Accessed 8 May 2017).

${ }^{20}$ Marie Dacke, Emily Baird, Marcus Byrne, Clarke Scholtz and Eric Warrent, 'Dung Beetles Use the Milky Way for Orientation', Current Biology 23, (18 February 2013): 298-300.

${ }^{21}$ Freya Matthews, 'Planet Beehive', Australian Humanities Review 50 (May 2011):

171, http://www.australianhumanitiesreview.org/archive/Issue-May2011/mathews.html (Accessed 8 May 2017). See also: David Biello, 'Insects Provide Billions in Free Services', Scientific American [online] (3 April 2006), http://www.scientificamerican.com/article.cfm?id=insects-provide-billions (Accessed 8 May 2017). 
${ }^{22}$ Diana Thater, Visual voyage: Milky Way to the Virgo Cluster, 2015. Nine-monitor video wall and media player, 9:35 min loop, HDTV visual excerpt from 'Runaway Universe' (2000), Courtesy NOVA/WGHB and PBS, Tom Lucas Productions. Documentation of the work available: http://www.thaterstudio.com/collections/view/works/science-fiction/ (Accessed 8 May 2017)

${ }^{23}$ Dacke, et al. 'Dung Beetles'.

${ }^{24}$ Shannon Te Ao, 'Part Tree, Part Canoe', MFA Thesis, Massey University, Wellington, 2015: 41.

${ }^{25}$ Joseph Beuys, How to explain pictures to a dead hare (wie man dem toten Hasen die Blider erkärt), 26 November 1965. Schelma Gallery, Dusseldorf. For documentation see: https://www.artgallery.nsw.gov.au/collection/works/434.1997.9/ (Accessed 8 May 2017)

${ }^{26}$ Ann Temkin, 'Joseph Beuys: An Introduction to His Life and Work', in Thinking Is Form: The Drawings of Joseph Beuys (Philadelphia and New York: Philadelphia Museum of Art and Museum of Modern Art, 1993).

${ }^{27}$ Shannon Te Ao, 'Part Tree, Part Canoe', MFA Thesis, Massey University, Wellington, 2015: 45.

${ }^{28}$ I explore the connections between bar-tailed godwits and art history in a short post for the MECO research network. Susan Ballard 'Godwits and Planetary Aesthetics' 
MECO360, March 12016 https://www.uowblogs.com/meco/2016/03/01/godwitsand-planetary-aesthetics/ (accessed 7 May 2017).

${ }^{29}$ Stephen T. Garnett and Gabriel M. Crowley, 'The Action Plan for Australian Birds 2000', Australian Government, Department of the Environment and Energy https://www.environment.gov.au/node/14674 (Accessed 8 May 2017)

${ }^{30}$ Department of Environment and Conservation New South Wales, 'Recovery Plan for the Bush Stone-curlew Burhinus Grallarius' (Department of Environment and Conservation: Sydney, 2006), http://www.environment.nsw.gov.au/resources/nature/recoveryplanBushStonecurlew .pdf (Accessed 8 May 2017)

${ }^{31}$ Mahasweta Devi, 'Pterodactyl', in Imaginary Maps, trans. Gayatri Chakravorty Spivak (London: Routledge, 1993), 95-196.

${ }^{32}$ Spivak, Death of a Discipline, 72.

${ }^{33}$ Devi in Spivak, Death of a Discipline, 80.

${ }^{34}$ Agnieszka Golda and Martin Johnson in conversation with the author, studio visit: Mount Keira, Wollongong, 19 July 2016.

${ }^{35}$ Agnieszka Golda and Martin Johnson in conversation with the author, studio visit: Mount Keira, Wollongong, 19 July 2016.

${ }^{36}$ Object was exhibited as part of the International Society for Electronic Arts (ISEA) exhibitions in Hong Kong, May 2016. A copy of the full video is available here: Jinyi 
Wang and Nathan Hughes [Black Moss], 'Object' Technoculture: an online journal of technology in society, 6 (Creative Works) 2016.

http://tcjournal.org/drupal/vol6/blackmoss (Accessed 8 May 2017).

${ }^{37}$ Spivak, Death of a Discipline, 101.

${ }^{38}$ Neel Ahuja, 'Postcolonial Critique in a Multispecies World', PLMA: Modern

Languages Association 124, no. 2 (March 2009): 556-63.

${ }^{39}$ Ahuja, 'Postcolonial Critique', 556.

${ }^{40}$ Ahuja, 'Postcolonial Critique', 559. 